\title{
Spatial Theory and Method for the Study of Religion
}

\author{
KIM KNOTT \\ University of Leeds
}

\begin{abstract}
From an examination of recent social and cultural theory and selected work on place and space by scholars of religion I draw together resources for the development of a spatial methodology for the study of religion. In order to identify the key elements of this methodology, I discuss relations between the body and space, the dimensions, properties and aspects of space, and its dynamics, including the mutual imbrication of space, the "sacred" and sacralization. Consideration is given briefly to the application of a spatial approach, its strengths and weaknesses.
\end{abstract}

\section{Location of Religion in Contemporary Western Society}

Having considered the relationship between religion, locality and community for several years in the late 1990s, in 2001 I embarked on a more theoretical project to develop the necessary scholarly tools to analyse the location of religion in contemporary western society. "Location" is the key word here. Whilst it was self-evident that religion resided in its places of worship and organisations, in new movements and, arguably, in various "spiritual" beliefs and practices, it was not clear to what extent religion inhered in other, ostensibly secular, places. Inspired by the practised gaze of de Certeau (1984) and Foucault's interrogations of public institutions (1977; 1993), I determined to consider whether, and in what ways, religion was located "in the very fabric of the secular" (Carrette 2000, 152) by looking intently at various apparently non-religious places. I had in mind specific 
places at several scales: body, object, community, locality, organisation. My first thought experiments involved thinking about the location of religion in the street corner by my house, my daughter's school playground and the walk to my local park.

In thinking deeply about these places I realised that such an exercise of location would require two things: first, a theory and method of analysing both places and the socio-spatial process of location, and, secondly, some form of operational conceptualisation of religion (the object to be located). Both would take time and hard work to develop as I was not satisfied by any existing methods and definitions, and could thus take nothing "off the shelf". The results of the work that followed are described in Part I of my book, The Location of Religion: A Spatial Analysis (Knott 2005). In Part II they are then applied in the first of several case studies (in this case, of the left hand). In this article I shall not dwell on the way in which I pursued the question of the conceptualisation of religion (set in a field of religious/secular knowledge-power relations) ${ }^{1}$, but on the former issue, of spatial theory and method. $^{2}$

As a scholar of religions formed in the discipline (some would say "field") of religious studies with its traditions of history, phenomenology and engagement with the social sciences, I was well aware of the literature on sacred space, and had also come into contact, through my studies on religion and locality, with the geography of religion. ${ }^{3}$ The initial problem with these was their predication upon religion or the sacred either as an essential aspect of human experience or the landscape or as a condition of the domain to be studied. In my view I needed an approach to place and location that did not import religion or the sacred through its theoretical

\footnotetext{
${ }^{1}$ For a discussion, see Chapter 3 (Knott 2005).

2 This paper was first given at the seminar on "Ritualized Spaces in Religion and Everyday Life", organised by the Graduate School of Cultural Interpretations and Department of Folklore Studies, University of Helsinki in collaboration with the Finnish Literature Society, 16-17 December 2004. It was informed by research undertaken in 2004/05 in conjunction with a project funded by the Arts and Humanities Research Council in the UK (B/IA/AN5276/APN17687) on "Locating religion in the fabric of the secular".

${ }^{3}$ For a discussion of these, see Chapter 4 (Knott 2005).
} 
precepts or methods. ${ }^{4}$ Thus I turned first to another group of specialists - social and cultural theorists of space. ${ }^{5}$ Their work formed the basis of the spatial approach I developed. When I returned later to scholars of religion who had considered spatial issues I saw that some of their work was indeed useful and, furthermore, that - like religion in a secularist milieu-as scholars of religion they had been marginalised in the formation of late-modern discourse on space and place. I shall turn to their contribution shortly.

\section{Resources for a Spatial Approach: Social and Cultural Theory}

Influenced by my earlier interest in a grounded theoretical and inductive approach to religion in locality (Knott 1998; 2000), my starting point for developing a spatial approach was theories of place (from Martin Heidegger and Maurice Merleau-Ponty to Yi-Fu Tuan, and, more recently, Edward Casey and Christopher Tilley). Feminist and post-modern critics of the phenomenology of place, however, soon made me question the captivating discourse of the primacy of place (e.g., the geographer Gillian Rose and, from the study of religions, Judy Tobler). Moreover, a question I asked at a public lecture led me to reconsider the appropriateness of a focus on "place". I asked Doreen Massey why she had moved from such a focus to one based on space, and thus from the seemingly particular and local to the general - a move I thought surprising in a feminist scholar. She answered - as a postmodern theorist of the geography of globalisation as much as a feminist - that the notion of "space" had, in the 1990s, been opened up to scrutiny and criticism, that it was no longer confined to Cartesian conceptions of the abstract and geometric, but was understood, in configuration with time,

\footnotetext{
${ }^{4}$ Given my later conclusions about the relationship between religious and secular discourse and practice, this turned out to be a somewhat naïve starting point. The question remains whether a reductive approach in the study of religions can ever really free itself from the historical baggage of the place of religion in the formation of secular disciplines. I am suggesting that even the latter carry values, ideas and attitudes that - if not actually religious - are shaped in the West by the Judeo-Christian past and its process of secularisation.

${ }^{5}$ This group, as I suggest in my book $(2005,90)$, forms part of what Peter Berger refers to as the "secular internationale" (2002). Arguably, they are as guilty of marginalising and/or ignoring the role of religion as some phenomenologists of religion are of either ontologising it or accepting it uncritically.
} 
as complex, dynamic and relational. Experimentally, I followed her move from place to space, reading her work and that of several other postmodern geographers (David Harvey, Rob Shields, Ed Soja) before turning to their sources of inspiration, Henri Lefebvre and Michel Foucault.

It was from their work that I developed the elements of a spatial approach that could be applied to the problem of locating religion. ${ }^{6}$ These elements are:

- The body as the source of "space";

- The dimensions of space;

- The properties of space;

- The aspects of space;

- The dynamics of space.

In this section I shall briefly examine each of these in the context of social and cultural theory, and will show their relevance for thinking about religion (though not how they enable us to locate religion within the secular as that would require a discussion of their meaning and interrelationship which there is not space for here). In the following section I shall turn to those resources within the study of religions which further illuminate this process before showing how a spatial methodology may be applied and reflecting briefly on its strengths and weaknesses.

The first principle of a spatial approach for the location of religion is the foundational role of the body for our experience and representation of space, and - because spatial metaphors are central for cognition and representation (Lakoff \& Johnson 1980; 1999) - for talking about our environment, the nature of our society and relationships, time and progress, and the sacred. In a short essay from 1768 Kant noted the way in which the intersection of

\footnotetext{
${ }^{6}$ These are discussed in Chapters 1 and 2 of my book (2005) and summarised as "the terms of a spatial analysis" in Chapter 5. In the final section of this article I argue that together they constitute a spatial methodology.

7 "Space" is a concept which allows us to talk, write and share ideas about an aspect of human and social experience, in this case the experience of our situatedness vis-à-vis the body, others and the world about us. Like "religion", it is a concept with a contested history. When I use the word "space" - henceforth without quotation marks - I mean the concept or notion of space not the phenomenon of space.
} 
the surfaces associated with the three spatial dimensions and their relation to the body generated "the concept of regions in space", notably of "above and below", "right and left" and "front and back" $(1968,38)$. Furthermore, he noted that difference was an inherent feature of the body: the hands, for example, though appearing the same, are "incongruent counterparts" (p.41). First, the different positions, parts, regions of space are understood relationally by way of our bodies. And, secondly, the way we orient places physically and mentally derives from our asymmetrical bilaterality. In short, our bodies allow us to experience and conceptualise the relationships between things, places, persons (as well as regions), and to identify differences, for "in the constitution of bodies differences, and real differences at that, can be found" (p. 43). ${ }^{8}$ As the cognitive philosophers Lakoff and Johnson have suggested, our minds make fruitful use of the body's nature, internal and external relations, situatedness and movement in space to produce spatial metaphors that can be used to articulate differences and relationships between persons, things, places and values (1980; 1999; Johnson 1987). ${ }^{9}$

The centrality of the body for social life and the cultural order which shapes us and with which we engage was recognised in different ways by Lefebvre and Foucault. In his conclusion to The Production of Space Lefebvre wrote:

The whole of (social) space proceeds from the body, even though it so metamorphoses the body that it may forget it altogether - even though it may separate itself so radically from the body as to kill it. The genesis of a far-away order can be accounted for only on the basis of the order that is nearest to us - namely the order of the body. Within the body itself, spatially considered, the successive levels constituted by the senses [...] prefigure the layers of social space and their interconnections. $(1991,405$.

\footnotetext{
${ }^{8}$ For further discussion of Kant's essay for body, space and place, see Casey $(1997,205-209)$ and J. Z. Smith (1987, 27-28). Mark Johnson approves of Kant's analysis of body and the regions of space but - and here he speaks for most late-modern scholars - rejects his Cartesian conclusion regarding reason, imagination and the body (1987, xxvi-xxix).

${ }_{9}^{9}$ Their ideas have been taken up by Veikko Anttonen in his discussion of the role of body and territory for the conceptualisation of the sacred (1996a; 1996b; 2003; 2005). See following section.
} 
It was the failure of Western thought to remain true to this fact, and instead to sever body from mind, subject from object, and mental from social, that led to "the body's metamorphosis into abstractions, into signs of non-body" (p. 407). ${ }^{10}$ Whilst Lefebvre suggests that it is possible to forget the foundational nature of the body for social space Foucault implies that a similar act of forgetting can occur in thinking about the body itself. More than the sum of its physical parts and biological processes, it is "the place where the most minute and local social practices are linked up with the large scale organisation of power" (Dreyfus \& Rabinow 1983, xxvi). ${ }^{11}$ The body is at times the place where a cultural order plays itself out; it may become a representation of that order, and will certainly be conditioned and disciplined by it.

How do these ideas about the body as the source of spatial perception and conception, and as a spatial outcome of cultural and political practices relate to the location of religion? As Mary Keller has suggested (writing of George Lakoff), the body "determines the conditions for the possibility of experience which prefigures the structures of knowledge" $(2002,67)$. Religions, which must necessarily work within these parameters, must likewise be formed on the basis of this bio-spatial starting point. Furthermore, the act of trying to locate religion and the procedure for doing so, like any other process of location, must be informed by the spatial sense we have ourselves acquired by being embodied and spatially oriented, and through our capacity for thinking and representing things spatially.

Moving from the body as foundational for human experience of space to the nature of space itself, I shall attempt now to decode "space" by considering its various dimensions, properties and aspects. This categorisation emerges from the work of Lefebvre (1991) and Foucault (1986), gathering a

\footnotetext{
${ }^{10}$ In Part II of my book (2005) I show how different principles in the Western symbolic order (e.g., good/evil, God/Devil, male/female, salvation/damnation) gain arguably their fullest expression through the hands and sides of the body, that is, by reference to "right" and "left". This is not merely a binary ordering, but a hierarchical dualistic one which uses the body's asymmetry to reproduce notions of cultural difference and status.

${ }^{11}$ The way in which bodies are sacralised in conformity with religious symbols, values and theological ideas demonstrates Foucault's point. Furthermore, bodies and their behaviour are disciplined by religions. Individual and collective strategies which challenge and resist the power wrought by religions are also worked on and through the body.
} 
late-modern perspective in the critical scholarship of contemporary social and cultural geographers such as Massey (1993a; 1993b; 1994), Harvey (1990; 1993), Shields (1991; 1999), Soja (1996), Merrifield (1993; 2000), and Elden (2004).

By "dimensions of space" I mean to take a unified view of space in which, following Lefebvre (1991, 11), physical, mental and social space are brought together. Contemporary theories of space do not restrict this notion to geometric coordinates and the physical domain (though a recent call for the "rematerialisation" of social and cultural geography [Jackson 2000] suggests that it is this dimension in recent times that has been marginalised). Space, as any reading of the recent literature on identity will show (in terms such as the politics of location, the critical space of the margin, thirdspace etc.), is also a mental or conceptual dimension, one which may float free of any physical mooring, but which uses the notion of space metaphorically and may provide a means of imagining and giving expression to human possibility, cultural difference, the imagination itself, as well as social relations. The last of these is one of the many ways in which space can be said to be social. From the side of the social, Lefebvre made the telling observation that "social relations [...] have no real existence save in and through space" $(1991,404)$. All such relations - whether for love or struggle, whether faceto-face or electronic - are spatial. Whatever one's view of space, whether Cartesian geometric or postmodern globalised, it is relational: the relation between points on a grid, between different places (or parts of space), or between people. But is space itself social? According to Massey, it is certainly socially constituted (and bodily constituted, as I have already suggested). Late twentieth century conceptions of space, informed by Lefebvre's account of space as produced and reproduced by human action and interaction, are avowedly social.

Religion, which is inherently social, must also exist and express itself in and through space. Moreover, it plays its part in the production and reproduction of social space. Transnational religious communities, for example, root themselves in national contexts and in a variety of local places. They 
express themselves through the mobility of their adherents, in the printed word and in cyberspace, and through their spatial acts, whether mundane, ritual, performative, or even terrorist. They also generate new spaces, for example, the diasporic space - at once real and imagined, physical and social.

Space is not something other than or further to the physical, mental and social dimensions that constitute it. It is their dynamic summation.

Space does not eliminate the other materials or resources that play a part in the socio-political arena, be they raw materials or the most finished of products, be they businesses or "culture". Rather, it brings them all together and then in a sense substitutes itself for each factor separately by enveloping it. (Lefebvre 1991, 410-411.)

Space is not an empty container or tabula rasa in which other things are placed or against which they happen. It is multi-dimensional. Conceptually, "space" is what Lawson (2001) referred to as a compound linguistic closure in which other things (or, more properly their concepts or names) are brought together, gathered or configured. ${ }^{12}$ The multiple possibilities of such a process of gathering or configuration are indeed one of the ways in which the notion of space could be said to remain open despite the appearance of closure. But space has other properties too that keep it open and dynamic.

Configuration, along with simultaneity, extension and power, are what I have referred to as "the properties of space". I have drawn them from Foucault's reflection on the current "epoch of space" in his 1967 lecture "Des espaces autres" (1986). There he referred briefly but explicitly to "configuration", "simultaneity" and "extension" (pp. 22-23) ${ }^{13}$ in an essay that assumed a direct and necessary relationship between space and power (a view shared by Lefebvre).

We are in the epoch of simultaneity: we are in the epoch of juxtaposition, the epoch of the near and far, of the side-by-side, of the dispersed. We are at

\footnotetext{
${ }^{12}$ It was Martin Heidegger who introduced the notion that places "gather" or hold things together (versammlung) in his essay on "Building, Dwelling, Thinking" (1993).

${ }^{13}$ Foucault prefers "site" to "extension" $(1986,23)$.
} 
a moment, I believe, when our experience of the world is less that of a long life developed through time than that of a network that connects points and intersects with its own skein [...] Our epoch is one in which space takes for us the form of relations among sites. (Foucault 1986, 22-23.)

This idea of contemporary space as constituted by synchronic relations and diachronic extensions is shared by Lefebvre (1991, 37) and Massey (1993a, 155-156). Massey illustrates simultaneity with her account of London's Kilburn High Road in its internal complexity and diversity and its dynamic interconnection with other current global sites (1993b, 64-66; 1994, 152-154). But Kilburn High Road, as well as being formed in part by the network of contemporary relations that constitutes it - global economic markets, the transnational links of its residents and visitors, the languages, religions and cultures of consumption that pass along it with their global connections - contains its history within itself as an ever-present "etymology of location" (Lefebvre 1991, 37). This is place as palimpsest, as de Certeau would have it.

The revolutions of history, economic mutations, demographic mixtures lie in layers within it, and remain there, hidden in customs, rites, and spatial practices. The legible discourses that formerly articulated them have disappeared, or left only fragments in language. This place, on its surface, seems to be a collage. In reality, in its depth, it is ubiquitous. A piling up of heterogeneous places. Each one, like a deteriorating page of a book, refers to a different mode of territorial unity, of socio-economic distribution, of political conflicts, and of identifying symbolism [...] (de Certeau 1984, 201.)

A particular place - a French Romanesque cathedral, for instance, or a British Sikh gurdwara in what was once a factory or school - enfolds its social, physical and cultural history within it, the various phases in its development layering through it and sometimes engaging instrumentally with one another along the way.

From none of these spatial properties - of configuration, simultaneity and extension - is power absent. In so far as space is social and mental, so 
is it power-full. Without an arena of struggle, a space to produce and to shape, ideas and beliefs, principles and values remain ephemeral and ungrounded. They lack "an appropriate morphology" (Lefebvre 1991, 417). Lefebvre draws elsewhere on a religious example to make his point:

What is an ideology without a space to which it refers, a space which it describes, whose vocabulary and links it makes use of, and whose code it embodies? What would remain of a religious ideology - the Judaeo-Christian one, say - if it were not based on places and their names: church, confessional, altar, sanctuary, tabernacle? What would remain of the Church if there were no churches? The Christian ideology, carrier of a recognisable if disregarded Judaism [...], has created the spaces which guarantee that it endures. (Lefebvre 1991, 44.)

Churches and other places of worship, as symbolic places, are one means by which religious ideas about the divine, the human community, and the ritual process of producing sacred space are given a material presence.

The force of ideology is not the only way in which power is exercised in space, however, as the performance of resistance and subversion also has spatial consequences. Demonstrations in London early in 2003 against the war in Iraq, for example, in which religious as well as secular political organisations were in evidence, not only temporarily transformed the streets down which they passed and the bodies of their participants but reproduced themselves in countless cities, in the pages of the world's press, and electronically on numerous websites. Furthermore, they entered the space of consciousness, not only of the demonstrators, but of those who supported the war, as a reminder of the force of resistance.

These examples show how difficult it is to discuss the dynamic nature of space systematically. Whilst writing about the spatial property of power I have referred already to the aspects and dynamics of space and its production and reproduction. To make these clearer and to show their relevance for religions, however, I must go into a little more detail.

By "aspects of space" I turn again to the work of Lefebvre, this time to his spatial triad, three interconnected aspects which refer to the way in 
which space is perceived, conceived and lived by people $(1991,33,38-40) .{ }^{14}$ Arguably, the processes of perception and conception are not as easily separable as this distinction implies (Lakoff \& Johnson 1999, 37), but Lefebvre was nevertheless able to develop a useful analytical tool by distinguishing them. His first aspect, the way in which space is generated, used and perceived by people in everyday life, Lefebvre called "spatial practice".${ }^{15}$ It is taken-for-granted, a matter of common sense, not reflected upon (even if, at times, it rubs up against the conceived spatial order). Spatial practice has its own logic, at the generative centre of which lies the body. It incorporates a repertoire of gestures, bodily movements and behaviours which may take account of the physical and social spaces in which they occur, but which are only partially disciplined by them. In taking the shortest walk from one place to another, for example, we may deviate from the footpaths provided for us by planners. The repertoire of spatial practice may be co-opted in ritual or liturgy, in possession or procession, but the same repertoire also informs the activities of the health club, the army training barracks and youth subcultures. It is a question of spatial practice made sacred. ${ }^{16}$ Religion, in its physical presence, social orderings, and cultural forms, is a consequence of spatial practice, though it is the attribution of meaning that gives such practice its character as "religious".

With Lefebvre's second and third aspects we move from the way space is perceived to the ways in which it is represented and then apprehended. Lefebvre distinguished what some of his English-speaking commentators have referred to as "representations of space" from "spaces of representation" ${ }^{17}$ By the former he meant conceived space, those dominant, theoret-

\footnotetext{
${ }^{14}$ This triad has been extensively treated by social and cultural geographers, particularly Shields (1991; 1999), Merrifield (1993), Stewart (1995) and Soja (1996). Two scholars who have used it to discuss religion are Chivallon (2001) and Gorringe (2002). I consider it in detail in Chapter 2 (2005).

${ }^{15}$ This behavioural aspect was also treated in different ways by de Certeau (1984) and Bourdieu (1990).

${ }^{16}$ See Catherine Bell (1992) on practice made sacred in ritual, and J. Z. Smith (1987) on the sacralisation - through ritual practice - of place.

${ }^{17}$ Stewart $(1995,610)$ and Shields $(1999,161,165)$ prefer the translation "spaces of representation" to Nicholson-Smith's "representational space" (Nicholson-Smith was the translator of Lefebvre's La Production de l'espace into English).
} 
ical, often technical representations of space that are produced by planners, architects, engineers and scholars $(1991,38) \cdot{ }^{18}$ Such spaces are expressions of ideology, in particular, of the dominant order (Lefebvre's principal example [1991, 282-291] was the "abstract space" of modernism with its geometric, visual and phallic "formants"). As if to illustrate the historical transition from Lefebvre's "absolute space" of medieval Europe to that of abstract modernism, the architectural historian Nikolaus Pevsner, in his consideration of the work of Walter Gropius, wrote:

Yet the character of the new buildings is entirely un-Gothic, anti-Gothic. While in the thirteenth century all lines, functional though they were, served the one artistic purpose of pointing heavenwards to a goal beyond this world, and walls were made translucent to carry the transcendental magic of saintly figures rendered in coloured glass, the glass walls are now clear and without mystery, the steel frame is hard, and its expression discourages all otherworldly speculation. It is the creative energy of this world in which we live and work and which we want to master, a world of science and technology, of speed and danger, of hard struggles and no personal security, that is glorified in Gropius's architecture. (1960, 216-217.)

Yet even this secular age of modernism, with its this-worldly orientation, continued to contain the religious traces of earlier periods. In Britain, medieval gothic, and, far more numerous, nineteenth century neo-gothic buildings (both religious and non-religious in character) dwelt amongst the glass, steel and concrete, the tower blocks. But more recently, as one contemporary architect of mosques has noted,

the academic inquisition against modernism has provided numerous opportunities. As the design canons of modernist minimality and pure composition have come under attack, there has been a new air of respectability for the study of ornament, craft, tradition, form, symbol, text, inscriptions, and, above all, the philosophical underpinnings of architectural intentions. (Haider 1996, 41.)

\footnotetext{
${ }^{18}$ Lefebvre tended to equate the act of representation with the work of the dominant order, arguably giving insufficient consideration and weight to active, demotic acts of representation.
} 
This "new air of respectability" has made room yet again for theological codes to impress themselves on the landscape, particularly in those cities informed by a multiculturalist and multi-faith agenda.

Conceived space, of course, in not limited to the built environment, though this is certainly one of the principal spatial means by which the dominant order may assault our senses. In my book I also consider state and civic ceremonies and human rights discourse as examples of contemporary social and mental spaces in which we may see secularist and religious pluralist agendas represented.

And what of Lefebvre's third aspect? A "space of representation", as distinct from those we have just considered, is "directly lived through its associated images and symbols" (Lefebvre 1991,39). It is experienced by those (such as artists, writers, performers, and perhaps innovators of ritual and religious symbol) who make imaginative and symbolic use of physical space in order to realise the possibility of resisting the power of a dominant order, regime or discourse. ${ }^{19}$ Whilst Lefebvre's own examples of lived space were associated with underground resistance and politically-inspired carnival and performance, a persuasive religious example is provided by Christine Chivallon in her account of the space of identity created by Black Christian experience in England. African Caribbean religious ideas and practices form "a space which serves to deconstruct the racial order inscribed in the British spaces and to replace them with representations, more mental than material, which are free from this categorisation" (Chivallon 2001, 477). At once, they allow this group to live with the imposed order, to challenge it with a non-racist narrative, and to transcend it by allowing something different and more just to be imagined.

These aspects, which were not seen by Lefebvre as historical stages but as ever-present spatial possibilities that vie for ascendancy, are themselves

\footnotetext{
${ }^{19}$ It was in the context of discussing lived space that Lefebvre used the word "moments", by which he meant those brief experiences of presence that "are revelatory of the totality of possibilities contained in daily existence" (Shields 1999, 58). He had already articulated "a theory of moments" in his 1961 book, recently translated into English as The Critique of Everyday Life: Foundations for a Sociology of the Everyday (2002). This is arguably where Lefebvre's thinking is most informed by mysticism and the surreal (see Shields 1999, 57-59).
} 
an illustration of the dynamism of space. Space does not, of course, exercise agency, but people's agency is continually expressed in and through it. Furthermore, as Lefebvre was keen to show, spaces are not only products. At times they may reproduce themselves (a successful space becoming the model for other such spaces, for example in the case of some religious buildings, commercial outlets, commodities, even rituals and laws). They also produce new but different spaces: a ritual gathering in a sacred space may, for example, spawn new social groups or cultural products which themselves have a physical form.

As we have seen in this section, social and cultural theory has reconceived "space" as dynamic, in terms of its relationship to power, history and time, its condition of simultaneity and the various ways in which it is experienced and represented. No longer is it seen as the passive container or backdrop for human activity. It is thoroughly enmeshed in embodiment and everyday practice, knowledge and discourse, and in processes of production and reproduction, and consequently it is enmeshed in religion no less than in other areas of social and cultural life. Opening up contemporary "space" to closer scrutiny and identifying some of its constituent elements is an important stage in the process of turning theory into a workable methodology which can then be applied to various cases. Before returning to the question of spatial methodology, we must first consider whether the study of religions can offer anything additional to this process.

\section{Resources for a Spatial Approach: The Study of Religions}

What theoretical and methodological resources have been developed by scholars in the discipline of religious studies (also known as the science of religion, Religionswissenschaft, comparative religion, the study of religion) which might contribute to a spatial approach? I stress "theoretical and methodological" resources because there can be no doubt that such scholars have unearthed and described extensive data of a spatial kind relating to religion, but it is not my intention to discuss these data here. Furthermore, in devising a range of conceptual tools and models for the study of reli- 
gion, scholars have often utilised spatial terminology, though they have not generally examined the spatial implications of doing so: e.g., notions of insider/outsider; experience-near/experience-distant; right hand sacred/left hand taboo; religious mapping; dimensions of religion. But how far have scholars of religion, from the perspective of their own discipline and object of study, contributed to theory and method of an overtly spatial kind?

If we were to examine the bibliographies provided by geographers of religion - that academic group we most commonly associate with a spatial approach to religion - we might be forced to conclude that the contribution of scholars from outside the discipline of geography was small. Such is the nature of all disciplines that those within them tend to know best the work of their immediate colleagues and less well the work produced on similar subjects by those from other disciplines. Writing in 1965, Erich Isaac, a well known geographer, suggested that "geography of religion" was for geographers, and that those in comparative religion and theology with an interest in space and geography should stick to "religious geography", a distinction that was largely maintained until the 1990s when calls were made for a more informed understanding of differing approaches (Kong 1990; Cooper 1992; Raivo 1997). ${ }^{20}$ A major book on the geography of religion published in the same decade, however, failed to mention the work of any scholars of religion other than Mircea Eliade and Ninian Smart (the latter not known in particular for an interest in space or geography) (Park 1994). ${ }^{21}$ One might, for example, have expected to see a discussion of the work on sacred space of Paul Wheatley (1971) or Jonathan Z. Smith (1978c; 1987). Two recent journal reviews of new directions in geographical work on religion have been much more interdisciplinary and open in their approach. Kong (2001) and Holloway and Valins (2002) have noted work done by those beyond their own discipline and have begun to develop a new, reciprocal agenda more fitted to contemporary social and cultural trends and scholarly interests. I can do no more than commend these contributions here, however, as, like earlier

\footnotetext{
${ }^{20}$ One exception was the work in the 1970s of the German scholar of Religionswissenschaft, Manfred Büttner $(1974 ; 1980)$.

${ }^{21}$ Park's more recent contribution on "Religion and geography" (2005) is a summary article based on material from his book and is no improvement in this regard.
} 
reviews in the geography of religion, they discuss studies that are broadly empirical rather than theoretical or methodological in orientation.

Arguably, we would do better to look to scholarship on a contemporary scholarly theme - that of globalization and localization - rather than the discipline of geography for contributions to theory and method. There we see that the formative theoretical work of Roland Robertson (1992; 1995) was informed by knowledge of the sociology of religion, the nature of religious change, and religio-political movements. Subsequently, scholars such as Beyer (1994), Eade (1997), Lehmann (2002) and Coleman (2000) have contributed to theorising the relationship between religion and globalization, whilst localization, the importance of "local particularity" and the value and nature of a locally-based approach to the study of religion have been discussed by Martikainen (2004), Jenkins (1999) and Knott (1998; 2000) respectively.

Undoubtedly the chief spatial focus in the study of religion, and the area in which the contribution of scholars within the discipline of religious studies has been greatest, is space and the sacred, and it is to that area I shall now turn.

In their introduction to American Sacred Space, Chidester and Linenthal (1995) open their discussion by distinguishing between the poetics and politics of sacred space, a contrast they borrow from Stallybrass and White (1986), noting that it is the former - poetics - that has been at the forefront of the study of religion. By way of exemplification, they begin, not with Eliade's work on the sacred Center (which is at the heart of so many summary accounts of sacred space), but with van der Leeuw's 1933 inventory of sacred sites from Religion in Essence and Manifestation. His series of homologies - home, temple, settlement, pilgrimage site, human body - and linked synecdoches - hearth, altar, sanctuary, shrine and heart - have been formative in identifying the key terms, for a scholarly discussion of the poetics of the sacred. Chidester and Linenthal note, however, that, irrespective of his account of the presence of the sacred, van der Leeuw recognised "that the positioning of a sacred place was a political act, whether that 
positioning involved, in his own terms, selection, orientation, limitation, or conquest" $(1995,8)$. In addition, he was aware that a sacred place was powerful "because it was appropriated, possessed and owned" (p. 9); whilst containing sacred objects, their owners and servants, it excluded others (p. 9); and, furthermore, people could be divided or exiled from it and could experience its loss (pp. 9-10). So, whilst Chidester and Linenthal acknowledge that scholars of religion have chiefly been attentive to van der Leeuw's phenomenological typology of sacred sites, they suggest that he also laid the ground work for later discussions of the construction and politics of such sites. Their own focus on contestation, in relation to which they present three domains - the natural, the built and the mythic - "that represent overlapping and interweaving interpretations of space as sacred" (p. 13), owes something to his work.

Chidester and Linenthal acknowledge that their "insistence on the contested character of sacred space must seem strange for readers who are only familiar with the vantage point adopted and promoted by Mircea Eliade" $(1995,16)$, and it is to him - the more familiar figure in this scholarly landscape - that I now turn. Eliade's poetics of sacred space has provided a frame of reference for all subsequent scholars of sacred geography, whether followers or critics. His axioms - of sacred space as other or set apart from ordinary, profane space, as the "Center" or axis mundi through which communication between different domains is possible, and as the manifestation of the "Real" (or hierophany) (Eliade 1959, 26) - have become foundational for scholarly articulations of the meaning and power of the sacred in space and time. They have also become the means by which later scholars have moved the discussion of "sacred space" from its roots in an ontological conception of the holy or sacred to a critical interrogation of the human processes involved in making space "sacred" - in producing, constructing, contesting and imagining sites the position, value and meaning of which are held by their creators, owners and followers to be non-negotiable and categorically special and different. In the American context, for example, Eliade's axioms provide both the starting point for Belden C. Lane's phe- 
nomenological enquiry into the poetics of American sacred landscape (1988, 15) and, latterly, for Chidester and Linenthal's own subversive, critical approach to the contested nature of "sacred space" in general and American sites in particular $(1995,17)$.

It is not only on Eliade's contribution that these authors build but on the developmental work of Jonathan Z. Smith who, in 1971, voiced his respectful criticism of his senior colleague's theory in a lecture entitled "The Wobbling Pivot" (1978a). One of Smith's queries addressed Eliade's focus on the Center at the expense of the periphery, and this led him to elucidate his own useful dichotomy between two "coeval existential possibilities", "a locative vision of the world (which emphasizes place) and a utopian vision of the world (using the term in its strict sense: the value of being in no place)" (1978a, 101). He developed these two cosmologies in his later essay "Map Is Not Territory", as an imperial "map of the world", ideologically self-serving and legitimizing, which seeks "to overcome incongruity by assuming the interconnectedness of all things" (1978c, 308-309), and a utopian map which reverses the locative, "perceives terror and confinement in interconnection, correspondence and repetition" (p. 309) and seeks to escape to a new world. He noted also a third, unnamed, in-between map in which "incongruous elements [are allowed] to stand", thus making a space for thought and creativity (p. 309). ${ }^{22}$ Smith's maps contribute in two ways to spatial theory and method for the study of religion. First, they employ spatial terminology. His proposition that "map is not territory" takes a meta-spatial conception (map) from its geographical context (territory) and applies it in a cosmological one thus providing a different lens through which to see and analyse different types of worldview. Secondly, I suggest it evokes the idea, which Smith went on to develop in his 1987 book, To Take Place, that place is more than a natural or material space. It is lived first and foremost in hearts and minds, and is socially organised. Physical spaces,

\footnotetext{
${ }^{22}$ I have discussed Smith's three maps in relation to Lefebvre's dialectical triad (Knott 2005, 100-101). Arguably, there is a closer fit between them and Ed Soja's interpretation of Lefebvre's triad (as Firstspace, Secondspace and Thirdspace) (Soja 1996).
} 
whether "sacred" or "profane" may follow; they take shape on the basis of cosmologically and socially constructed maps of the world.

It was Smith who, in his work in the 1970s and 1980s, dislodged theory on sacred space from its previous base in a phenomenological conception of both the sacred and space/place and re-engaged it with social and cultural constructionist approaches from anthropology and sociology, through scholars such as Durkheim, Levi-Strauss, Douglas and Geertz. ${ }^{23}$ At the heart of To Take Place was the answer to his question "What if space were not the recipient but rather the creation of the human project? What if place were an active product of intellection rather than its passive receptacle?" (1987, 26). "Human beings are not placed, they bring place into being" (p. 28), and they do this - at least in the case of sacred places - through ritual. Ritual, that creative process whereby people make a meaningful world that they can inhabit, "is not [...] a response 'to the sacred'; rather, something or someone is made sacred by ritual" (p. 105). This is taken up by later scholars, Catherine Bell, of course, in Ritual Theory, Ritual Practice (1992), but also scholars whose focus has been space rather than ritual per se. Barbara Daly Metcalf, for example, in her introduction to the edited collection, Making Muslim Space, notes that the majority of essays in the book emphasize "that it is ritual and sanctioned practice that is prior and that creates 'Muslim space"' $(1996,3)$, not vice versa. Chidester and Linenthal refer to the sacred as "situational, relational, and frequently, if not inherently, contested [...] a bi-product of this work of sacralization" $(1995,6)$, but they also note that this process is "perhaps best understood as a particular type of embodied spatial practice" (p. 9). Sacred place is an outcome of sacralization, but sacralization itself, in this view, is contingent upon spatial "techniques of the body" (Mauss cited in Chidester \& Linenthal 1995, 10).

This dual spatial engagement with sacred-making activities is most fully explored by Veikko Anttonen (1996a; 1996b; 2003; 2005) for whom space

\footnotetext{
${ }^{23}$ For his critique of phenomenological perspectives and preference for a social constructionist one, see Smith's essay “The Influence of Symbols upon Social Change: A Place on which to Stand" (1978b, 129-146) and chapters 1 and 2 of To Take Place (1987, 1-46). For Smith's selfaccount (his "bio-bibliographical essay"), see "When the Chips Are Down" (2004).
} 
- specifically body and territory - is more than just the product of sacralization or an aspect of the process (in the form of spatial practice). It is central to the generation of the "sacred" as a category boundary.

For Anttonen, "human body" and "territory" are fundamental conceptual structures for the generation of discourse and practice pertaining to the "sacred". They are not only "domains of experience whose social meanings are symbolically construed", but - owing to our mind/body interaction - "are cognitively organised at the preconceptual level" (Anttonen 1996b, 41). ${ }^{24}$ Their value for the utilisation of the "sacred" as a category boundary, however, derives not just from their foundational nature, but from their inter-relationship, or "co-extensiveness as bounded entities" (p. 41). Drawing on the work of Herbst on "what happens when we make a distinction" (1993), Anttonen stipulates the importance for cognitive category formation and its cultural applications of the notions of "inside" and "outside" and a third space between them, the boundary (1996b, 42). The human body has both an inside and an outside, the latter being co-extensive with the inside of the territory which it inhabits. The boundaries between body, territory and beyond - that separate both the inside of the body from the territory and that which is outside the territory from those within it - become culturally-dependent cognitive markers for distinguishing between entities on the basis of their value and for establishing rules for their engagement and transformation:

Human beings have the dispositional property to invest the boundary-points of categories of for instance time, space and the human body with special referential value and inferential potential. This capacity is activated in places set apart as sacred. (Anttonen 2002, 31.)

The "sacred" as a category boundary both "separates" different domains (such as body from territory, male from female, person from animal) and "binds" them together. "It is generated as a boundary in situations when

\footnotetext{
${ }^{24}$ Anttonen too makes use of the work of George Lakoff and Mark Johnson in arguing for the conceptual significance of body and space.
} 
the focus of a community or a person shifts from the inside to the outside" or vice versa $(1996 \mathrm{~b}, 43)$; and ritual is the principal cultural process for managing it.

In this theory of the sacred - in which the "sacred" has no intrinsic ontological status but is generated in boundary situations - the mind, working unconsciously with embodied notions of space and consciously with whatever cultural tools are available to it, has developed the capacity to give significance and meaning to natural and social boundaries. This "attribution of sacrality" (2005) has been explored by Anttonen in various ways, particularly in relation to terms for the sacred in various languages (1996a; 1996b; 2005) and the use of such terms to mark actual places and boundaries (1996a; 1996b, 47-56; 2003, 298-304). As he has noted, "ethnographic accounts, folklore genres, as well as religious texts, are pregnant with explicit or implicit references to boundaries of space and territory as well as of human body as prime locations of the discourse of the sacred" (2005, 190). Anttonen concludes:

The notion of "sacred" - and the act of sacralization - becomes more open to empirical verification when it is theorized on the basis of the actions, events and intentions of cultural agents in specific contexts as they make distinctions between spaces, mark them for specific uses, create visible and invisible boundaries, and establish cultural conventions of behavior to deal with those boundaries. (Anttonen 2005, 198.)

This spatial theoretical approach may provide a powerful resource for examining, in particular, places that are ostensibly non-religious or secular but to which sacrality is nevertheless attributed.

One sociologist of religion who has recently turned her attention to ambiguous sacred spaces is Sophie Gilliat-Ray. ${ }^{25}$ In her consideration of the sacralization of sacred space in British public institutions such as the hospitals (2005b) and the Millennium Dome (2005a), she notes that the attribution of sacrality or "sacredness" in conventional places of worship arises

\footnotetext{
${ }^{25}$ As this section deals specifically with resources within the study of religions I have not considered the relevant work of the anthropologist Marc Augé on "non-places" (1995).
} 
as a consequence of shared rituals and acts of prayer, but that it "cannot so easily occur in sacred spaces in public institutions because there is no on-going consensus that the meaning of the actions performed within them [has] some generally shared long-term significance" (2005a, 364). Anttonen's theory, which may be reinforced by but does not depend on agents' own understandings of the meanings of their actions or of what constitutes the "sacred", may be brought to bear on such spaces to uncover the operation of boundaries and their significance for the marking of values, rules and distinctions. Although Gilliat-Ray does not do this, she does offer her own valuable insight on what sacred spaces in public institutions can provide for the people who use them, many of whom were not nurtured in religious communities and have no formal religious affiliation.

Sites of spiritual activity that are in some senses generic or universal and where there is an absence of explicit religious symbols or architecture associated with one single faith community, allow space for people to explore their own sometimes muddled beliefs (or lack of them) [...] People can undertake their own private interpretive work [...] Such spaces are thus perfectly suited to the needs of an increasing number of people who have forgotten (or who may have never known) the protocols of visiting religious buildings. (GilliatRay 2005a, 364-365.)

Gilliat-Ray's examination of the affinity between such unconventional sacred spaces and the needs of the people who may pass through them raises questions about both the nature and function of secular sacred space and the process of sacralization in late-modernity that form a new context for the debate in the study of religions on sacred space.

What do these resources from the study of religion add to those from social and cultural theory that were discussed earlier? From their focus on religion and the sacred, they certainly reiterate some of its principal claims. The idea that "space" is best understood as multi-dimensional, for example, was of importance for J. Z. Smith in his work on the social meaning of place and placing, and for both him and Chidester and Linenthal in their accounts of cosmological and mythic space. That space is produced and reproduced 
through social struggle (Lefebvre) is also reinforced in their work on the production and contestation of sacred space. Furthermore, it is arguable that Smith's discussion of cosmological maps explores ideas not dissimilar to those of Lefebvre in the latter's examination of perceived, conceived and lived space.

In these and other ways scholars of religion who have discussed spatial issues have trodden some of the same theoretical ground as those theorists we looked at earlier. However, they have also contributed something novel through their work on sacralization and the sacred. Yet this work remains almost entirely undiscovered beyond the community of scholars working on religion. J. Z. Smith has argued that place is brought into being through ritual: sacralization produces meaningful places, "sacred spaces". It is legitimate to ask whether any scholarly discussion of the production of space would now be complete without a consideration of his work. Furthermore, Anttonen has suggested that this sacred-making activity is contingent upon human embodiment and socio-spatial location, which together provide the basis for cognitive categorisation and the emergence of the "sacred" as a category boundary. Between them, Anttonen and Smith have made a case for the inseparability of notions of space and the sacred. But are such developments of spatial theory marginal because they focus on sacrality and the production of sacred space? To concede this would be to fail to recognise the centrality of processes of sacralization at work in all societies, including secular ones, and in relation to a wide variety of social, cultural and ideological concerns and interests, including but not limited to religion.

\section{A Spatial Methodology, Its Applications, Strengths and Weaknesses}

In the earlier section on resources from social and cultural theory I listed several elements I consider to be important for a spatial approach - the body as the source of space, the dimensions, properties and aspects of space, and the dynamism of space - to which we might now add, as part of the latter, the interfacing of space and sacralization. In my book I refer to them, in chapter 5 , as "terms of a spatial analysis" for the location of religion, although, as I 
acknowledged at the outset of this article, understanding how such terms assist in that particular project requires a discussion of "religion" that is beyond my remit here. When taken together such terms could be said to constitute a methodology, a system of principles, practices, and procedures applied, in this case, to the study of religion. Rather than a set of practical methods - which we often associate with the idea of methodology - this approach is analytical and interpretive. Although it would certainly inform the collection of data, it is not a guide to the means by which those data should be collected. My own choice of data collection methods continues to be ethnographic, particularly the combined use of documentary methods, participant observation and interviewing, all of which have their own rules, procedures and ethics. A spatial methodology is of particular use and value in the analysis of data (though it is certainly true that a researcher who had collected data without the intention of conducting a spatial approach might well need to revisit the field with its spatial characteristics in mind).

A methodology based on the spatial elements or terms listed above requires a series of analyses, thinking about one's chosen research object or place from the perspective of, first, body, then spatial dimensions, then properties, and so on. The terms themselves are a form of shorthand, so, for a full analysis it is necessary to be conversant with the theoretical background which informs them. It is not enough, for example, simply to have "body" in mind when thinking about an object or place; one needs an awareness of the way in which spatial conceptions have emerged from our embodiment, of how particular spaces or places are derived from bodies and their location in space, and of the way in which the body itself is a produced space acted upon and informed by orders and regimes of various kinds. To use another example, it is hard to see how one could proceed to analyse an object or place from the perspective of the aspects of space without some awareness of the theoretical arguments which underpin ideas about perceived, conceived and lived space.

To make full use of this spatial methodology, then, requires considerable theoretical engagement and analytical commitment. It demands time and 
effort, as I found when I used it to make a study of the location of religion in the left hand (Knott 2005, Part II). It had originally been my intention to apply a spatial approach to several case studies in the second half of my book, but I found that the nature of the analysis was both more time-consuming and more productive than I had imagined it would be. This admission may discourage others from proceeding with a spatial methodology. However, I have found that it is not always necessary to apply all the elements of the methodology in every case. Interesting results may be yielded by pursuing an analysis based solely on the dimensions of space, or its properties, or dynamics. ${ }^{26}$ Thinking spatially - about religion or anything else - is extremely fruitful and often produces new and unexpected insights, whether one focuses on all or just some of the elements I discussed earlier.

Although I devised this approach for the purpose of locating religion in apparently non-religious or secular places, I now think that it can be used for an intensive investigation of any object or place (or representation thereof). This methodology is a powerful analytical tool which - as Lefebvre suggested - reunites disparate disciplines and fields in a spatial examination which attempts to take seriously issues of embodiment and cognition, representation, production and reproduction, simultaneity, power, and time and history as they inform space. For the study of religion this methodology offers a novel approach, and a timely one in so far as it enables scholars to engage with an important theme within contemporary social and cultural theory.

\footnotetext{
${ }^{26}$ In the work that Myfanwy Franks and I have conducted on locating religion in the fabric of secular organisations (a high school and medical centre) we have excluded Lefebvre's spatial aspects from our analysis, and have concentrated on the body as the source of space, and on spatial dimensions and properties (Knott \& Franks, in press).
} 
Bibliography

\section{Anttonen, Veikko}

1996a Ihmisen ja maan rajat. "Pyhä" kulttuurisena kategoriana. Helsinki: Suomalaisen Kirjallisuuden Seura (with a summary in English "The Making of Corporeal and Territorial Boundaries: The Sacred as a Cultural Category").

1996b Rethinking the Sacred: The Notions of "Human Body" and "Territory" in Conceptualizing Religion. - Thomas A. Idinopulos \& Edward A. Yonan (eds), The Sacred and its Scholars: Comparative Religious Methodologies for the Study of Primary Religious Data, 36-64. Leiden: E. J. Brill.

2002 Identifying the Generative Mechanisms of Religion: The Issue of Origin Revisited. - Ilkka Pyysiäinen \& Veikko Anttonen (eds), Current Approaches in the Cognitive Study of Religion, 14-37. London and New York: Continuum.

2003 Sacred Sites as Markers of Difference: Exploring Cognitive Foundations of Territoriality. - Lotte Tarkka (ed.), Dynamics of Tradition: Perspectives on Oral Poetry and Folk Belief, 291-305. Helsinki: Studia Fennica Folkloristica (Finnish Literary Society).

2005 Space, Body, and the Notion of Boundary: A Category-Theoretical Approach to Religion. - In this volume.

\section{Augé, Marc}

1995 (1992) Non-Places: Introduction to an Anthropology of Supermodernity. London and New York: Verso.

\section{Bell, Catherine}

1992 Ritual Theory, Ritual Practice. New York and Oxford: Oxford University Press.

\section{Berger, Peter L.}

2002 Secularization and De-secularization. - Linda Woodhead \& Paul Fletcher \& H. Kawanawi \& David Smith (eds), Religions in the Modern World, 291-298. London and New York: Routledge.

\section{Beyer, Peter}

1994 Religion and Globalization. London: Sage.

\section{Bourdieu, Pierre}

1990 The Logic of Practice. Cambridge: Polity.

\section{Büttner, Manfred}

1974 Religion and Geography: Impulses for a New Dialogue Between Religionswissenschaftlern and geography. - Numen 21, 165-196.

1980 Survey Article on the History and Philosophy of the Geography of Religion in Germany. - Religion 10(2), 86-119. 


\section{Carrette, Jeremy R.}

2000 Foucault and Religion: Spiritual Corporality and Political Spirituality. London and New York: Routledge.

\section{Casey, Edward S.}

1996 How to Get from Space to Place in a Fairly Short Stretch of Time: Phenomenological Prolegomena. - Steven Feld \& Keith H. Basso (eds), Senses of Place, 13-52. Santa Fe: School of American Research Press.

1997 The Fate of Place: A Philosophical Enquiry. Berkeley: University of California Press.

\section{Chidester, David \& Edward T. Linenthal (eds)}

1995 American Sacred Space. Bloomington and Indianapolis: Indiana University Press.

\section{Chivallon, Christine}

2001 Religion as Space for the Expression of Caribbean Identity in the United Kingdom. - Environment and Planning D: Society and Space 19, 461-483.

\section{Coleman, Simon}

2000 The Globalisation of Charismatic Christianity: Spreading the Gospel of Prosperity. Cambridge: Cambridge University Press.

\section{Cooper, Adrian}

1992 New Directions in the Geography of Religion. - Area 24, 123-129.

\section{de Certeau, Michel}

1984 The Practice of Everyday Life. Berkeley: University of California Press.

\section{Dreyfus, Hubert L. \& Paul Rabinow}

1983 Michel Foucault: Beyond Structuralism and Hermeneutics. New York and London: Harvester Wheatsheaf.

\section{Eade, John (ed.)}

1997 Living the Global City: Globalization as a Local Process. London and New York: Routledge.

\section{Elden, Stuart}

2004 Understanding Henri Lefebvre: Theory and the Possible. London and New York: Continuum.

\section{Eliade, Mircea}

1959 (1957) The Sacred and the Profane: The Nature of Religion. San Diego: Harcourt Brace Jovanovitch.

\section{Foucault, Michel}

1977 (1975) Discipline and Punish: The Birth of the Prison. London: Penguin. 
1986 Of Other Spaces (Des espaces autres). - Diacritics 16(1), 22-27.

1993 (1963) The Birth of the Clinic: An Archaeology of Medical Perception. London: Routledge.

\section{Gilliat-Ray, Sophie}

2005a "Sacralising" Sacred Space in Public Institutions: A Case Study of the Prayer Space at the Millennium Dome. - Journal of Contemporary Religion 20(3), 357-372.

2005b From "Chapel" to "Prayer Room": The Production, Use, and Politics of Sacred Space in Public Institutions. - Culture and Religion 6(2), 281-302.

\section{Gorringe, Timothy}

2002 A Theology of the Built Environment: Justice, Empowerment, Redemption. Cambridge: Cambridge University Press.

\section{Haider, Gulzar}

1996 Muslim Space and the Practice of Architecture: A Personal Odyssey. - Barbara Daly Metcalf (ed.), Making Muslim Space in North America and Europe, 31-45. Berkeley: University of California Press.

\section{Harvey, David}

1990 The Condition of Postmodernity. Oxford: Basil Blackwell.

1993 From Space to Place and Back Again: Reflections on the Condition of Postmodernity. - J. Bird \& T. Curtis \& G. Putnam \& L. Tickner (eds), Mapping the Futures: Local Cultures, Global Change, 3-19. London and New York: Routledge.

\section{Heidegger, Martin}

1993 (1951) Building, Dwelling, Thinking. - David Farrell Krell (ed.), Martin Heidegger: Basic Writings, 343-363. London and New York: Routledge.

\section{Herbst, David P.}

1993 What Happens When We Make A Distinction. - Cybernetics and Human Knowing 2, 29-38.

\section{Holloway, Julian \& Oliver Valins}

2002 Placing Religion and Spirituality in Geography. - Social and Cultural Geography 3(1), 5-9.

\section{Isaac, Erich}

1965 Religious Geography and the Geography of Religions. - Man and the Earth, Series in Earth Sciences 3, 1-14. Boulder Colorado: University of Colorado Press.

\section{Jackson, Peter}

2000 Rematerializing Social and Cultural Geography. - Social and Cultural Geography 1(1), 9-14. 


\section{Jenkins, Timothy}

1999 Religion in English Everyday Life: An Ethnographic Approach. New York and Oxford: Berghahn Books.

\section{Johnson, Mark}

1987 The Body in the Mind: The Bodily Basis of Meaning, Imagination and Reason. Chicago and London: Chicago University Press.

Kant, Immanuel

1968 (1768) Concerning the Ultimate Foundation of the Differentiation of Regions in Space. - G. B. Kerferd \& D. E. Walford (eds), Kant: Selected Pre-Critical Writings and Correspondence with Beck, 36-43. Manchester: Manchester University Press; New York: Barnes and Noble.

\section{Keller, Mary}

2002 The Hammer and the Flute: Women, Power and Spirit Possession. Baltimore and London: The Johns Hopkins University Press.

\section{Knott, Kim}

1998 Issues in the Study of Religions and Locality. - Method and Theory in the Study of Religion 10, 279-290.

2000 Community and Locality in the Study of Religions. - Tim Jensen \& Mikael Rothstein (eds), Secular Theories on Religion: Current Perspectives, 87-105. Copenhagen: Museum Tusculanum Press.

2005 The Location of Religion: A Spatial Analysis. London and Oakville CT: Equinox.

\section{Knott, Kim \& Myfanwy Franks}

In press. Secular Values and the Location of Religion: A Spatial Analysis of an English Medical Centre. - Health and Place.

\section{Kong, Lily}

1990 Geography of Religion: Trends and Prospects. - Progress in Human Geography 14(3), 355-371.

2001 Mapping "New" Geographies of Religion: Politics and Poetics in Modernity. - Progress in Human Geography 25(2), 211-33.

\section{Lakoff, George \& Mark Johnson}

1980 Metaphors We Live By. Chicago and London: University of Chicago Press.

1999 Philosophy in the Flesh: The Embodied Mind and its Challenge to Western Thought. New York: Basic Books.

\section{Lane, Belden C.}

1988 Landscapes of the Sacred: Geography and Narrative in American Spirituality. New York: Paulist Press. 


\section{Lawson, Hilary}

2001 Closure: The Story of Everything. New York and London: Routledge.

\section{Lefebvre, Henri}

1991 (1974) The Production of Space. Oxford and Cambridge MA: Blackwell.

2002 (1961) The Critique of Everyday Life: Foundations for a Sociology of the Everyday. London and New York: Verso.

\section{Lehmann, David}

2002 Religion and Globalisation. - Linda Woodhead \& Paul Fletcher \& Hiroko Kawanawi \& David Smith (eds), Religion in the Modern World, 299-315. London and New York: Routledge.

\section{Martikainen, Tuomas}

2004 Immigrant Religions in Local Society: Historical and Contemporary Perspectives in the City of Turku. Åbo: Åbo Akademi University Press.

\section{Massey, Doreen}

1993a Politics and Space/Time. - Michael Keith \& Steve Pile (eds), Place and the Politics of Identity, 141-161. London: Routledge.

1993b Power-Geometry and a Progressive Sense of Place. - J. Bird \& T. Curtis \& G. Putnam \& L. Tickner (eds), Mapping the Futures: Local Cultures, Global Change, 59-69. London and New York: Routledge.

1994 Space, Place and Gender. Cambridge: Polity.

\section{Merleau-Ponty, Maurice}

1992 (1945) Phenomenology of Perception. London, Routledge, New York: Humanities Press.

\section{Merrifield, Andrew}

1993 Place and Space: A Lefebvrian Reconciliation. - Transactions of the British Institute of Geographers NS 18, 516-531.

2000 Henri Lefebvre: A Socialist in Space. - Philip Crang \& Nigel Thrift (eds), Thinking Space, 167-182. London and New York: Routledge.

\section{Metcalf, Barbara Daly (ed.)}

1996 Making Muslim Space in North America and Europe. Berkeley: University of California Press.

\section{Park, Chris}

1994 Sacred Worlds: An Introduction to Geography and Religion. London and New York: Routledge.

2005 Religion and Geography. - John Hinnells (ed.), The Routledge Companion to the Study of Religion, 439-455. London and New York: Routledge.

\section{Pevsner, Nikolaus}

1960 (1936) Pioneers of Modern Design: From William Morris to Walter Gropius. Harmondsworth: Penguin. 


\section{Raivo, Petri J.}

1997 Comparative Religion and Geography: Some Remarks on the Geography of Religion and Religious Geography. - Temenos 33, 137-149.

\section{Robertson, Roland}

1992 Globalization: Social Theory and Global Culture. London, Thousand Oaks, New Delhi: Sage.

1995 Glocalization: Time-Space and Homogeneity-Heterogeneity. - M. Featherstone \& S. Lash \& R. Robertson (eds), Global Modernities. 24-44. London, Thousand Oaks, New Delhi: Sage.

\section{Rose, Gillian}

1993 Feminism and Geography: The Limits of Geographical Knowledge. Cambridge: Polity.

\section{Shields, Rob}

1991 Places on the Margin: Alternative Geographies of Modernity. London and New York: Routledge.

1999 Lefebvre, Love and Struggle: Spatial Dialectics. London and New York: Routledge.

\section{Smith, Jonathan Z.}

1978a (1971) The Wobbling Pivot. - Jonathan Z. Smith, Map is Not Territory: Studies in the History of Religions, 88-103. Chicago and London: Chicago University Press.

1978b (1973) The Influence of Symbols upon Social Change: A Place on which to Stand. - Jonathan Z. Smith, Map is Not Territory: Studies in the History of Religions, 129-146. Chicago and London: Chicago University Press.

1978c (1974) Map is Not Territory. - Jonathan Z. Smith, Map is Not Territory: Studies in the History of Religions, 289-310. Chicago and London: Chicago University Press.

1987 To Take Place: Toward a Theory of Ritual. Chicago and London: University of Chicago Press.

2004 When the Chips Are Down. - Jonathan Z. Smith, Relating Religion: Essays in the Study of Religion, 1-60. Chicago and London: University of Chicago Press.

\section{Soja, Edward W.}

1996 Thirdspace: Journeys to Los Angeles and Other Real-and-Imagined Places. Cambridge MA: Basil Blackwell.

\section{Stallybrass, Peter \& Allon White}

1986 The Politics and Poetics of Transgression. London: Methuen.

\section{Stewart, Lynn}

1995 Bodies, Visions and Spatial Politics: A Review Essay on Henri Lefebvre's The Production of Space. - Environment and Planning D: Society and Space 13, 609-618. 


\section{Tilley, Christopher}

1994 The Phenomenology of Landscape. London: Berg.

\section{Tobler, Judy}

2000 "Home is Where the Heart Is": Gendered Sacred Space in South Africa. - Journal for the Study of Religion 13(1-2), 69-98.

\section{Tuan, Yi-Fu}

1977 Space and Place: The Perspective of Experience. Minneapolis: University of Minnesota Press.

\section{van der Leeuw, Gerardus}

1986 (1933) Religion in Essence and Manifestation. Princeton: Princeton University Press.

Wheatley, Paul

1971 The Pivot of the Four Quarters. Chicago: Aldine. 